\title{
The Vector-Borne Zoonotic Nematode Thelazia callipaeda in the Eastern Part of Europe, with a Clinical Case Report in a Dog in Poland
}

\author{
Leszek Rolbiecki $^{1, *(\mathbb{D}}$, Joanna N. Izdebska ${ }^{1} \mathbb{D}$, Marta Franke $^{2}$, Lech Iliszko ${ }^{3}$ and Sławomira Fryderyk ${ }^{1}(\mathbb{D}$ \\ 1 Department of Invertebrate Zoology and Parasitology, Faculty of Biology, University of Gdańsk, \\ Wita Stwosza 59, 80-308 Gdańsk, Poland; biojni@ug.edu.pl (J.N.I.); slawomira.fryderyk@ug.edu.pl (S.F.) \\ Veterinary Office, Lutowiska 68, 38-713 Lutowiska, Poland; marta.franke@onet.pl \\ 3 Department of Vertebrate Ecology and Zoology, Faculty of Biology, University of Gdańsk, Wita Stwosza 59, \\ 80-308 Gdańsk, Poland; leiliszko@gmail.com \\ * Correspondence: leszek.rolbiecki@ug.edu.pl; Tel.: +48-58-5236190
}

Citation: Rolbiecki, L.; Izdebska, J.N.; Franke, M.; Iliszko, L.; Fryderyk, S. The Vector-Borne Zoonotic Nematode Thelazia callipaeda in the Eastern Part of Europe, with a Clinical Case Report in a Dog in Poland. Pathogens 2021, 10, 55. https://doi.org/10.3390/ pathogens10010055

Received: 21 November 2020 Accepted: 7 January 2021 Published: 9 January 2021

Publisher's Note: MDPI stays neutral with regard to jurisdictional clai$\mathrm{ms}$ in published maps and institutional affiliations.

Copyright: (C) 2021 by the authors. Licensee MDPI, Basel, Switzerland. This article is an open access article distributed under the terms and conditions of the Creative Commons Attribution (CC BY) license (https:// creativecommons.org/licenses/by/ $4.0 /)$.

\begin{abstract}
Thelazia callipaeda is a zoonotic nematode transmitted by drosophilid flies. It causes ocular thelaziosis, a disease of carnivores, such as dogs, cats, and foxes, and also humans. The parasite has thus far been observed in various areas of Eurasia, including 20 countries within Europe. The present study documents its presence in the south-east region of Poland, near the Ukraine border. An adult nematode was removed from the conjunctival sac of a dog showing ocular inflammation and purulent discharge. The dog's precise origin is unknown. Based on its localization and morphometrical features, the nematode was identified as a Thelazia callipaeda adult male. The present study is the first report of T. callipaeda in a dog in Poland.
\end{abstract}

Keywords: Thelazia callipaeda; eyeworm; zoonotic nematode; thelaziosis; dog; Poland; Eastern Europe

\section{Introduction}

Thelazia callipaeda Railliet et Henry, 1910 (Spirurida, Thelaziidae) is a parasitic nematode of the eye known to cause thelaziosis, a parasite infection of carnivores, lagomorphs and humans [1,2]. The infection can manifest with conjunctivitis, epiphora, visual disturbances and even keratitis, and corneal ulceration (e.g., [3,4]). The parasite was first discovered over one hundred years ago in Punjab, India [5], and has been thus far observed in other areas of Asia, such as China, Myanmar, India, Indonesia, Thailand, Taiwan, South of Korea, Japan, Bangladesh, Nepal, Vietnam, and the former USSR [3,6-14], and in 20 countries in Europe [15,16]. Despite its wide area of distribution and significant pathogenic (including zoonotic) importance, the parasite has been identified only relatively rarely and in few localities; however, its distribution is potentially far greater, particularly since data obtained from veterinary practices are not always included in academic studies.

Previous records from Western, Central and Southern Europe suggest that the nematode may also occur in neighboring countries, such as Poland and Ukraine. The present study is the first report of T. callipaeda in a dog in Poland.

\section{Results}

\subsection{Case Report}

A stray dog was observed in Poland, in the border area with Ukraine (approx. $5 \mathrm{~km}$ from the border), from July 2019 (Figure 1). The dog's precise origin is unknown. The detailed fate of the dog in the period from the first to the second observation is also unknown. In November 2019, after adoption, the dog was subjected to a veterinary examination and the necessary treatments-castration, deworming, vaccinations, and treatment of skin mycosis. During the first veterinary examination, an inflammation, erythema and excessive purulence of both eyes, particularly in one eye, were also diagnosed. The dog was in 
general poor condition, thus, the ocular symptoms were not then linked to the presence of parasites. He was initially treated with eye drops containing antibiotic tobramycin and corticosteroid dexamethasone (Tobradex ${ }^{\circledR}$, S.A. ALCON-COUVREUR N.V., Belgium) for three weeks, but with no effect. At the subsequent examination, a nematode was found in one of the eyes. No worms were found in the other eye. Symptoms and eye irritation resolved several days after removal of the nematode and the administration of an antiparasitic drug composed of imidacloprid and moxidectin (Advocate ${ }^{\circledR}$, KVP Pharma + Veterinär Produkte GmbH, Kiel, Germany).

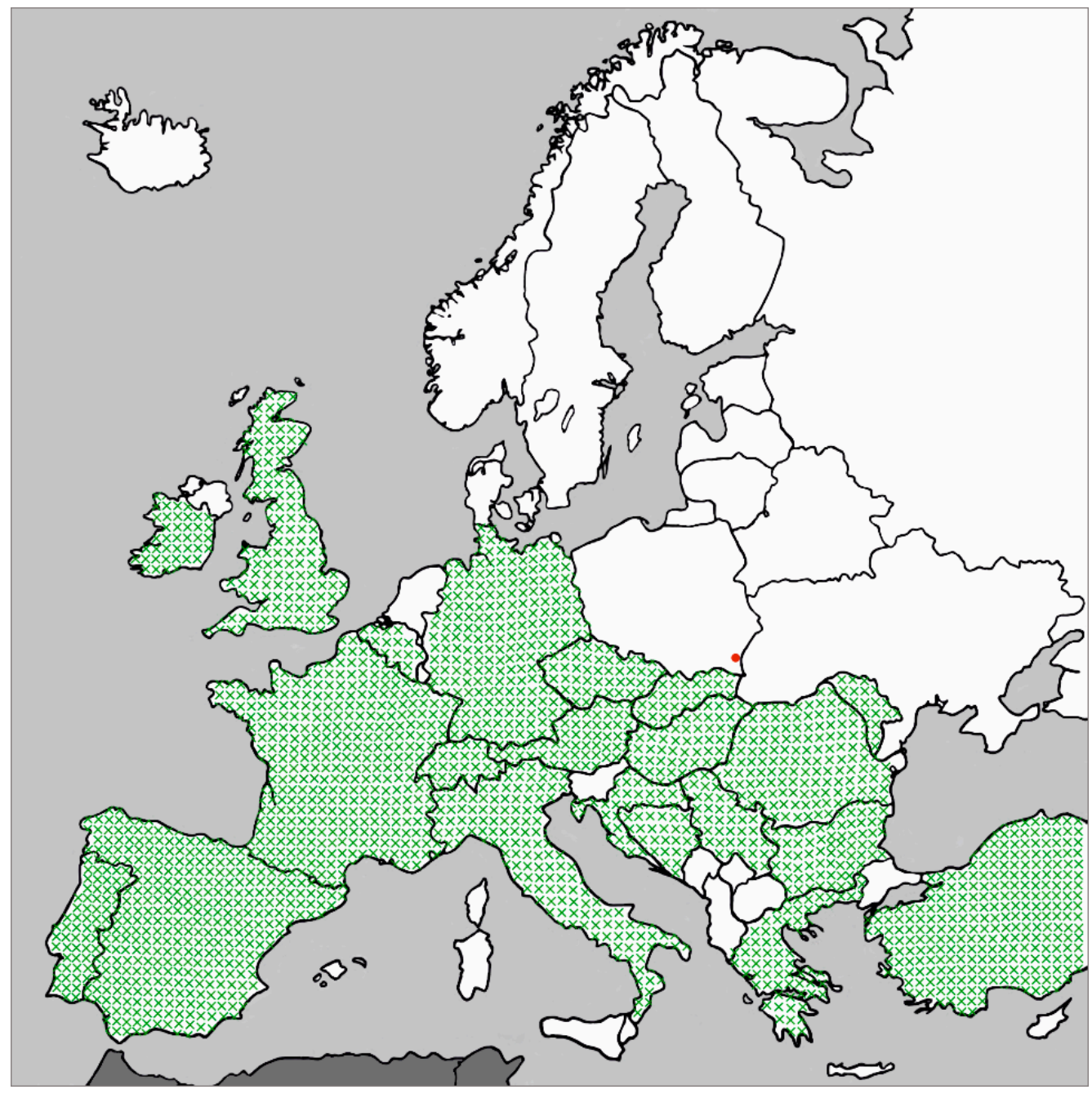

Figure 1. Geographical distribution of Thelazia callipaeda in Europe and locality (Krywe) of the present report in a dog in Poland.

\subsection{Description of the Nematode}

The isolated nematode (Figure 2) had a body length of $9.5 \mathrm{~mm}$ and a maximum width of $450 \mu \mathrm{m}$, while the width at the level of the oesophagus-intestinal junction was $265 \mu \mathrm{m}$. The caudal end was ventrally curved with pre-cloacal and post-cloacal papillae. The nematode had a clearly serrated cuticle, except for the buccal capsule. The buccal capsule was hexagonal, $25 \mu \mathrm{m}$ long and $30 \mu \mathrm{m}$ wide. The oesophagus was $580 \mu \mathrm{m}$ in length, while its width was $92.5 \mu \mathrm{m}$ at the posterior end and $60 \mu \mathrm{m}$ at the anterior end. The tail was $90 \mu \mathrm{m}$ long and showed two spicules; the left spicule was $1.88 \mathrm{~mm}$ long and the right spicule was $170 \mathrm{~mm}$ long. Based on its localization and morpho-anatomical and metrical features, the nematode was identified as a T. callipaeda adult male (Figure 2). 

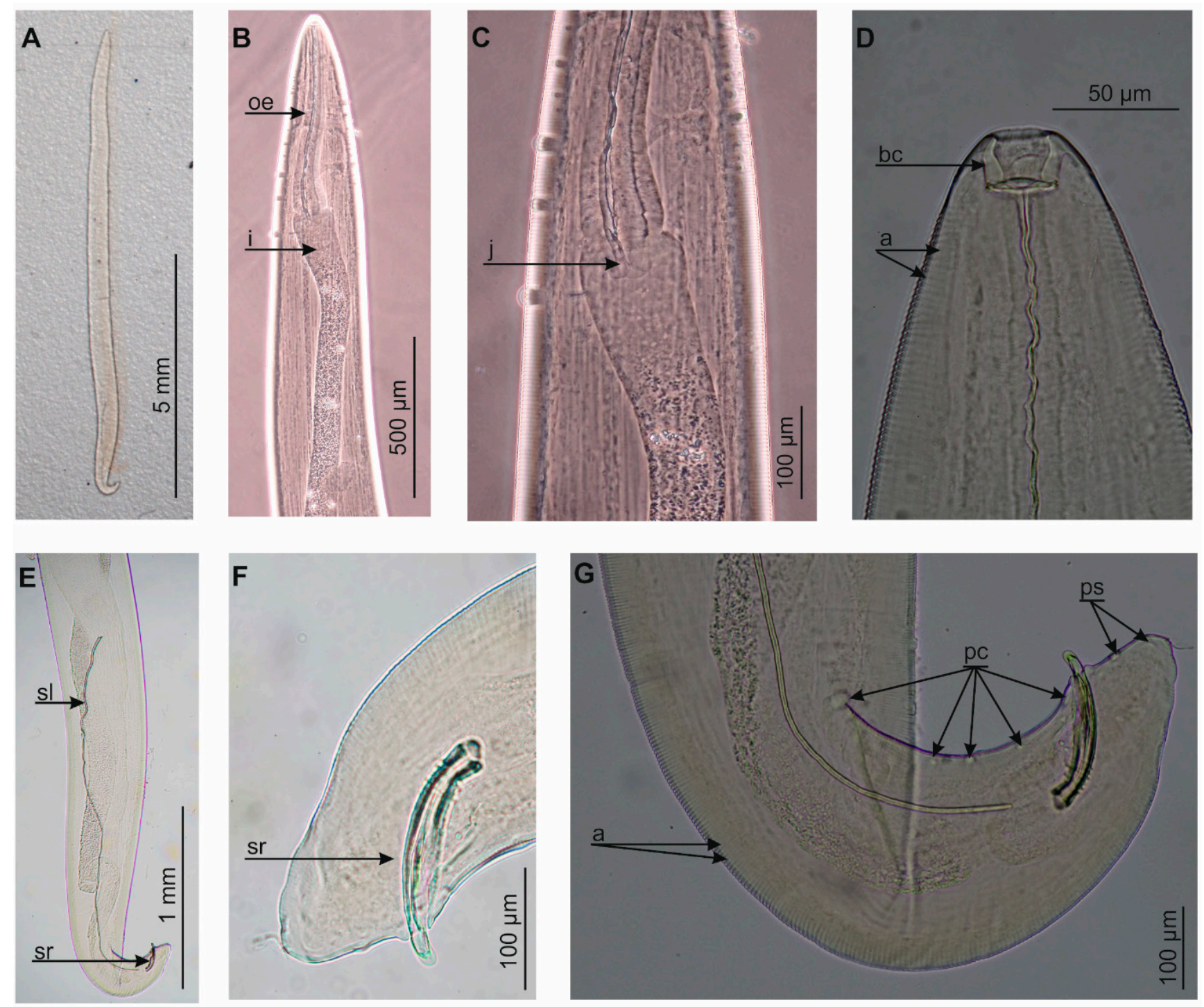

Figure 2. Thelazia callipaeda, (A) total view, (B) anterior end, (C) junction between oesophagus and intestine, (D) cephalic end, (E) posterior end, (F) tail, (G) tail and papillae; a: annellations, bc: buccal capsule, i: intestine, j: junction, oe: oesophagus, pc: pre-cloacal papillae, ps: post-cloacal papillae, sl: left spicule, sr: right spicule.

\section{Discussion}

In recent years, an increased number of T. callipaeda infection clinical cases have been observed throughout Europe (Figure 1) [4,15]. Carnivores are considered the main definitive hosts of T. callipaeda, including domestic carnivores, such as domestic dogs or domestic cats [17-20], or wild carnivores, such as the red fox Vulpes vulpes (Linnaeus, 1758), the European badger Meles meles (Linnaeus, 1758), the beech marten Martes foina (Erxleben, 1777), the Eurasian lynx Lynx lynx (Linnaeus, 1758), the golden jackals Canis aureus Linnaeus, 1758, the gray wolf Canis lupus Linnaeus, 1758, the racoon dog Nyctereutes procyonoides (Gray, 1834), the sable Martes zibellina (Linnaeus, 1758), the wild cats Felis silvestris Schreber, 1777, and the Asiatic black bear Ursus thibetanus G. [Baron] Cuvier, 1823 [21-26]. However, T. callipaeda has been reported also in other mammals, including the European rabbit Oryctolagus cuniculus (Linnaeus, 1758), the brown hare Lepus europaeus Pallas, 1778 [27,28] and, above all, in humans $[1,3,4,11,14]$. It is likely that the entire host range has not yet been discovered. It is also possible that under favorable circumstances, T. callipaeda may be able to increase its host spectrum and continue its spread by colonizing other less typical 
hosts. A particularly important consideration in this regard is its zoonotic significance and its increasing incidence in humans $[4,29,30]$.

Thus far, the only known intermediate hosts of T. callipaeda are the zoophilic flies of the subfamily Stegamininae (Diptera: Drosophilidae), i.e., Phortica variegata (Fallén, 1823) in Europe and P. kappa (Máca, 1977), P. magna (Okada, 1960), and P. okadai (Máca, 1977) in some parts of Asia (summarized in [31-33]). According to Huang et al. [34], P. kappa is found in Japan, P. magna in China and Japan, and P. okadai in China, Japan, Korea, and Russia. Thelazia callipaeda was first described in Asia at the beginning of the 20th century but has been recorded in European countries since the 1980s [35].

In Europe, $P$. variegata is widely distributed from southern areas up to Scandinavia and from the western to the European part of Russia, including Primorsky Krai [36]. This fly, under the former genus name Amiota variegata, was also indicated as the vector of T. callipaeda in Japan, but systematic revisions verified the status of the species as being present in Europe and the Caucasus [31-33]. In addition, T. callipaeda has been identified in some South-East Asia countries (e.g., India, Indonesia), where none of the four Phortica species known to act as its vectors could be found. Nevertheless, other Phortica species are present in this area, indicating that they may also act as vectors for T. callipaeda [32]. In general, the mode of transmission of these nematodes requires a considerable amount of research, as little is known of the flies representing this family and species identification is problematic [34]. However, it is significant that access to an intermediate host does not seem to limit its distribution across the whole of Eurasia.

Therefore, it has been predicted that Poland lies within the range of T. callipaeda [37]. Undoubtedly, an indication for this were the findings of T. callipaeda in the neighboring countries, i.e., Germany, the Czech Republic, and Slovakia [15] (Figure 1). Out of four records from Germany, two describe cases that are probably introduced [15]. However, cases described from Slovakia [38,39] and from the Czech Republic [40] are autochthonous. A recent finding from the Czech Republic (Prague) is considered the northernmost record of autochthonous canine thelaziosis in Europe [40]. In turn, in Poland, thus far, no comprehensively documented records are available. The only relevant data concerned a case in north-west Poland, probably introduced from Germany, which was presented at a national conference [41], but no extensive data in the form of a reviewed publication has so far been published.

Our present data, documented with helminthological identification and deposition of the material in an academic collection, originate from an area of south-east Poland, $5 \mathrm{~km}$ from the border with Ukraine. Disease symptoms observed in the dog (inflammation, erythema, and abundant purulent ocular discharge) were typical for T. callipaeda infection and quite severe. In fact, T. callipaeda adults and larval stages may cause lacrimation, conjunctivitis, and mild mucopurulent discharge $[3,42]$, with the severity and course depending on the intensity of infection or the presence of secondary bacterial infections [43]. Perhaps the high severity of symptoms was influenced by the general poor condition of the dog, as the intensity of the infection was low. Similar changes with a purulent discharge, conjunctival hyperaemia, were observed in dogs with a much higher level of infection [39]. As such national borders do not serve as barriers for parasites and their hosts, it is difficult to ascertain whether infection occurred in Poland, Ukraine, or in a third country. Nevertheless, our confirmation of the presence of T. callipaeda in this part of Europe is significant. According to previous studies, P. variegata is found throughout Europe, with the exception of its northern margin [44]. Its presence has been confirmed in Poland [45], although Drosophilidae are considered to be very poorly studied in the country, and their distribution, abundances, population dynamics, or seasonal dynamics have not been investigated in great detail so far. Undoubtedly, this constitutes a limitation to the predictions concerning the potential possibilities of T. callipaeda infection in different areas and seasons. Climatic factors may constitute a limiting parameter for the distribution of flies of this genus, and consequently of T. callipaeda, because they exhibit the preference for areas and seasons characterized by high temperatures [46]. However, the ecological preferences 
of P. variegata have not yet been studied in detail (e.g., in Poland [45]). Research was done locally, for instance in Italy or other selected regions of Europe, which made it possible to forecast potential distribution [31,32,44]. However, such data are difficult to refer to other regions of Europe characterized by different types of habitats or specific microclimatic factors. For sure, this requires detailed faunistic analyses by taking into account the specificity of local ecosystems. At the same time, information on the distribution of $P$. variegata is typically referred to the cases of mainly canine and human thelaziosis, based on singular observations and on limited areas. The disease is typically referred to rural areas, herding and hunting dogs, or other dogs with a great freedom of movement, which often have the access to areas constituting the natural habitat of P. variegata [32]. Without a doubt, the ongoing climate warming, as well as the host migration possibilities, which are difficult to control, may contribute to further records of T. callipaeda in other parts of Europe. Based on the presence of typical hosts in the fauna, it can be expected that this nematode has a wider distribution or its dispersion can be predicted. Phortica variegata was recorded also in Belarus [47], or in northern Europe, in Norway [48]. Undoubtedly, the growth and expansion of domestic predatory mammal populations, especially dogs whose global population is currently estimated at 900 million [49], can be one of the causes for the expansion of T. callipaeda distribution. They can cover large distances thanks to humans, as pets, but also locally, especially feral and stray dogs and other dogs with high freedom of movement. Another cause is the changes in the behavior of certain wild animals, such as fox synurbization.

These nematodes are typically detected based on the symptoms in their hosts, particularly the most commonly studied ones, i.e., domestic mammals. Therefore, a combination of comprehensive study and the monitoring of confirmed and potential intermediate hosts is needed to obtain a fuller picture of the current distribution and population dynamics of T. callipaeda. The present report of T. callipaeda in a dog in Poland stimulates further research studies in this area, which should include both domestic and wild animals.

\section{Materials and Methods}

\subsection{Description of the Host}

A stray dog named Smolnik, male, age $\sim 2$ years, weight $\sim 45 \mathrm{~kg}$, was sighted near the Orthodox church in Smolnik village $\left(49^{\circ} 12^{\prime} 55.4^{\prime \prime} \mathrm{N}, 22^{\circ} 41^{\prime} 45.1^{\prime \prime}\right.$ E). Smolnik had a Shepherd phenotype, similar to the Romanian Mioritic Shepherd breed. He was observed in Poland from around July 2019; he probably came from Ukraine. In November 2019, the dog was adopted by a resident of the Krywe village $\left(49^{\circ} 15^{\prime} 04.0^{\prime \prime} \mathrm{N}, 22^{\circ} 31^{\prime} 12.2^{\prime \prime} \mathrm{E}\right.$, Figure 1) and underwent veterinary examinations and treatments.

\subsection{Parasitological Analysis}

On 20 May 2020, the parasite was removed. The procedure was performed in a veterinary clinic with the dog under general anesthesia (dexmedetomidine and butorphanol) (Lutowiska, Poland). One nematode was removed from the conjunctival sac and fixed in $4 \%$ formaldehyde solution for study.

The nematode was placed in polyvinyl-lactophenol solution and identified to species level [1] using phase-contrast microscopy (Nikon Eclipse 50i). All measurements are in micrometers unless otherwise noted. Following analysis, the microscope slide was added to the scientific collections within the framework of the Collection of Extant Invertebrates in the University of Gdańsk, Department of Invertebrate Zoology and Parasitology, Poland.

Author Contributions: Conceptualization, L.R. and J.N.I.; methodology, L.R., J.N.I., M.F., L.I. and S.F.; investigation, L.R., J.N.I., M.F., L.I. and S.F.; resources, L.R., J.N.I., M.F., L.I. and S.F.; writingoriginal draft preparation, L.R. and J.N.I.; writing — review and editing L.R., J.N.I., M.F., L.I. and S.F. All authors have read and agreed to the published version of the manuscript.

Funding: This research received no external funding. 
Institutional Review Board Statement: The approval of the Ethics Committee was not required because the material for the research was obtained as a result of routine veterinary procedures related to the treatment of a sick dog.

Acknowledgments: We would like to thank the guest editor, Stefania Perrucci, and anonymous reviewers for helpful comments and suggestions on the manuscript.

Conflicts of Interest: The authors declare no conflict of interest.

\section{References}

1. Skrjâbin, K.I.; Sobolev, A.A.; Ivaškin, V.M. Spiruraty životnyh i čeloveka i vyzyvaemye imi zabolevaniâ, Telâsioidei. In Osnovy Nematodologii, 16, 4; Izdale'stvo Nauka: Moskva, Russia, 1967; pp. 12-58.

2. Otranto, D.; Dutto, M. Human thelaziasis, Europe. Emerg. Infect. Dis. 2008, 14, 647-649. [CrossRef] [PubMed]

3. Otranto, D.; Traversa, D. Thelazia eyeworm: An original endo and ecto- parasitic nematode. Trends Parasitol. 2005, 21, 1-4. [CrossRef] [PubMed]

4. do Vale, B.; Lopes, A.P.; da Conceição Fontes, M.; Silvestre, M.; Cardoso, L.; Coelho, A.C. Thelaziosis due to Thelazia callipaeda in Europe in the 21st century-A review. Vet. Parasitol. 2019, 275, 108957. [CrossRef]

5. Railliet, A.; Henry, A. Nouvelles observations sur les Thélazies, Nématodes parasites de l'oeil. C. R. Seances Soc. Biol. Fil 1910, 68, 783-785.

6. Bhaibulaya, M.; Prasertsilpa, S.; Vajrasthira, S. Thelazia callipaeda Railliet and Henry, 1910, in man and dog in Thailand. Am. J. Trop. Med. Hyg. 1970, 19, 476-479. [CrossRef] [PubMed]

7. Kosin, E.; Kosman, M.L.; Depary, A.A. First case of human thelaziosis in Indonesia. Southeast Asian J. Trop. Med. Public Health 1989, 20, 233-236. [PubMed]

8. Hong, S.T.; Park, Y.K.; Lee, S.K.; Yoo, J.H.; Kim, A.S.; Chung, Y.H.; Hong, S.J. Two human cases of Thelazia callipaeda infection in Korea. Korean J. Parasitol. 1995, 33, 139-144. [CrossRef] [PubMed]

9. Anderson, R.C. Nematode Parasites of Vertebrates: Their Development and Transmission, 2nd ed.; CABI Publishing: Wallingford, UK, 2000; pp. 404-407.

10. Yang, C.-H.; Tung, K.-C.; Wang, M.-Y.; Chang, S.-C.; Tu, W.-C.; Wang, K.-S.; Shyu, C.-L.; Lee, W.-M. First Thelazia callipaeda infestation report in a dog in Taiwan. J. Vet. Med. Sci. 2006, 68, 103-104. [CrossRef] [PubMed]

11. De, N.V.; Le, T.H.; Chai, J.-Y. The first human case of Thelazia callipaeda infection in Vietnam. Korean J. Parasitol. 2012, 50, 221-223. [CrossRef]

12. Akhanda, A.H.; Akonjee, A.R.; Hossain, M.M.; Rahman, M.A.; Mishu, F.A.; Hasan, M.F.; Akhanda, T.H. Thelazia callipaeda infestation in Bangladesh: A case report. Mymensingh Med. J. 2013, 22, 581-584.

13. Sah, R.; Khadka, S.; Adhikari, M.; Niraula, R.; Shah, A.; Khatri, A.; Suznne Donovan, S. Human thelaziasis: Emerging ocular pathogen in Nepal. Open Forum Infect. Dis. 2018, 5, ofy237. [CrossRef] [PubMed]

14. Otranto, D.; Mendoza-Roldan, J.A.; Dantas-Torres, F. Thelazia callipaeda. Trends Parasitol. 2020, 1-2. [CrossRef] [PubMed]

15. do Vale, B.; Lopes, A.P.; da Conceição Fontes, M.; Silvestre, M.; Cardoso, L.; Coelho, A.C. Systematic review on infection and disease caused by Thelazia callipaeda in Europe: 2001-2020. Parasite 2020, 27, 52. [CrossRef]

16. De Waal, T.; Lawlor, A.; Roulston, S. Case study: Ocular thelaziosis in a travelled dog. Vet. Irel. J. 2019, 9, $367-368$.

17. Hermosilla, C.; Bauer, C.; Herrmann, B. First case of Thelazia callipaeda infection in a dog in Germany. Vet. Rec. 2004, 154, 568-569. [CrossRef]

18. Soaresa, C.; Sousaa, S.R.; Anastácioa, S.; Matiasd, M.G.; Marquêsd, I.; Mascarenhasd, S.; Vieiraa, M.J.; de Carvalhob, L.M.; Otranto, D. Feline thelaziosis caused by Thelazia callipaeda in Portugal. Vet. Parasitol. 2013, 196, 528-531. [CrossRef]

19. Hammond, A. Thelazia callipaeda in a travelled dog in England. Vet. Rec. 2018, 183, 477. [CrossRef]

20. Hodžić, A.; Payer, A.; Duscher, G. The first autochthonous case of feline ocular thelaziosis in Austria. Parasitol. Res. 2019, 118, 1321-1324. [CrossRef]

21. Sargo, R.; Loureiro, F.; Catarino, A.L.; Valente, J.; Silva, F.; Cardoso, L.; Otranto, D.; Maia, C. First report of Thelazia callipaeda in red foxes (Vulpes vulpes) from Portugal. J. Zoo Wildl. Med. 2014, 45, 458-460. [CrossRef]

22. Odoevskaya, I.; Khrustalev, A.V.; Shaĭtanov, V.M.; Seriodkin, I.V.; Panayotova-Pencheva, M. Occurrence of the nematode Thelazia callipaeda Railliet and Henry, 1910 (Spirurida, Thelaziidae) in wild carnivores in the Russian Far East. Acta Zool. Bulg. 2015, 67, 561-566.

23. Mihalca, A.D.; Ionică, A.M.; D’Amico, G.; Daskalaki, A.A.; Deak, G.; Matei, I.A.; Șimonca, V.; Iordache, D.; Modrý, D.; Gherman, C.M. Thelazia callipaeda in wild carnivores from Romania: New host and geographical records. Parasites Vectors 2016, 9, 350. [CrossRef] [PubMed]

24. Seixas, F.; Travassos, P.; Coutinho, T.; Lopes, A.P.; Latrofa, M.S.; dos Pires, M.A.; Cardoso, L.; Otranto, D. The eyeworm Thelazia callipaeda in Portugal: Current status of infection in pets and wild mammals and case report in a beech marten (Martes foina). Vet. Parasitol. 2018, 15, 163-166. [CrossRef] [PubMed]

25. Gajić, B.; Bugarski-Stanojević, V.; Penezić, A.; Kuručki, M.; Bogdanović, N.; Ćirović, D. First report of eyeworm infection by Thelazia callipaeda in gray wolf (Canis lupus) from Serbia. Parasitol. Res. 2019, 118, 3549-3553. [CrossRef] 
26. Ionică, A.M.; Deak, G.; D'Amico, G.; Stan, G.F.; Chișamera, G.B.; Constantinescu, I.C.; Adam, C.; Lefkaditis, M.; Gherman, C.M.; Mihalca, A.D. Thelazia callipaeda in mustelids from Romania with the European badger, Meles meles, as a new host for this parasite. Parasites Vectors 2019, 12, 370. [CrossRef]

27. Otranto, D.; Dantas-Torres, F.; Malli, E.; DiGeronimo, P.M.; Brianti, E.; Testini, G.; Traversa, D.; Lia, R.P. Thelazia callipaeda (Spirurida, Thelaziidae) in wild animals: Report of new host species and ecological implications. Vet. Parasitol. 2009, 166, 262-726. [CrossRef]

28. Gama, A.; Pires, I.; Canado, M.; Coutinho, T.; Lopes, A.P.; Latrofa, M.S.; Cardoso, L.; Dantas-Torres, F.; Otranto, D. First report of Thelazia callipaeda infection in wild European rabbits (Oryctolagus cuniculus) in Portugal. Parasites Vectors 2016, 9, 236. [CrossRef]

29. Otranto, D.; Eberhard, M.L. Zoonotic helminths affecting the human eye. Parasites Vectors 2011, 4, 41. [CrossRef]

30. Fuentes, I.; Montes, I.; Saugar, J.M.; Latrofa, S.; Gárate, T.; Otranto, D. Thelaziosis in humans, a zoonotic infection, Spain, 2011. Emerg. Infect. Dis. 2012, 18, 2073-2075. [CrossRef]

31. Otranto, D.; Cantacessi, C.; Testini, G.; Lia, R.P. Phortica variegata as an intermediate host of Thelazia callipaeda under natural conditions: Evidence for pathogen transmission by a male arthropod vector. Int. J. Parasitol. 2006, 36, 1167-1173. [CrossRef]

32. Otranto, D.; Brianti, E.; Cantacessi, C.; Lia, R.P.; Máca, J. The zoophilic fruitfly Phortica variegata: Morphology, ecology and biological niche. Med. Vet. Entomol. 2006, 20, 358-364. [CrossRef]

33. Máca, J.; Otranto, D. Drosophilidae feeding on animals and the inherent mystery of their parasitism. Parasites Vectors 2014, 7, 516. [CrossRef]

34. Huang, J.; Gong, L.; Tsaur, S.-C.; Zhu, L.; An, K.; Chen, H. Revision of the subgenus Phortica (sensu stricto) (Diptera, Drosophilidae) from East Asia, with assessment of species delimitation using DNA barcodes. Zootaxa 2019, 4678, 1-75. [CrossRef] [PubMed]

35. Rossi, L.; Bertaglia, P. Presence of Thelazia callipaeda Railliet and Henry, 1910, in Piedmont, Italy. Parassitologia 1989, 31, 167-172. [PubMed]

36. Shtakelberg, A.A. Family Drosophilidae. In Keys to the Insects of the European Part of the USSR, Diptera and Siphonaptera; Bei-Bienko, G.Y., Steyskal, G.C., Eds.; E.J. Brill: Leiden, NY, USA; København, Danmark; Köln, Germany, 1989; Volume 5, pp. 393-665.

37. Madany, J.; Wrześniewska, K.; Milczak, A.; Abramowicz, B.; Winiarczyk, D. Wzrastające ryzyko wystapienia inwazji Thelazia callipaeda w Polsce, pasożyta powodującego objawy okulistyczne u psów i kotów. Życie Wet. 2018, 93, 175-178.

38. Čabanová, V.; Kocák, P.; Víchová, B.; Miterpáková, M. First autochthonous cases of canine thelaziosis in Slovakia: A new affected area in Central Europe. Parasites Vectors 2017, 10, 179. [CrossRef] [PubMed]

39. Balicka, A.; Lapšanská, M.; Halán, M.; Trbolová, A. Canine ocular thelaziosis in Slovakia a case report. Folia Vet. 2018, 62, 33-38. [CrossRef]

40. Jirků, M.; Kuchta, R.; Gricaj, E.; Modry, D.; Pomajbikova, K.J. Canine thelaziosis in the Czech Republic: The northernmost autochthonous occurrence of the eye nematode Thelazia callipaeda Railliet et Henry, 1910 in Europe. Folia Parasitol. 2020, 67, 10. [CrossRef] [PubMed]

41. Jańczak, D.; Wroński, K.; Słoński, A.; Przygodzka, M.; Lisowski, A.; Sałamatin, R.; Gołą, E. Imported Thelazia callipaeda infection in German pointer dog in Poland. In Proceedings of the XXVth Congress of the Polish Parasitological Society, Warsaw, Poland, 9-12 September 2019; Volume 65 (Suppl. 1), p. 130.

42. Ferroglio, E.; Rossi, L.; Tomio, E.; Schenker, R.; Bianciardi, P. Therapeutic and prophylactic efficacy of milbemycin oxime (interceptor) against Thelazia callipaeda in naturally exposed dogs. Vet. Parasitol. 2008, 154, 351-353. [CrossRef]

43. Yang, Y.J.; Liag, T.H.; Lin, S.H.; Chen, H.C.; Lai, S.C. Human thelaziasis occurrence in Taiwan. Clin. Exp. Optom. 2006, 89, 40-44. [CrossRef]

44. Palfreyman, J.; Graham-Brown, J.; Caminade, C.; Gilmore, P.; Otranto, D.; Williams, D.J.L. Predicting the distribution of Phortica variegata and potential for Thelazia callipaeda transmission in Europe and the United Kingdom. Parasites Vectors 2018, 11, 272. [CrossRef]

45. Zatwarnicki, T. Wywilżniowate (Drosophilidae). In Fauna Polski. Charakterystyka i Wykaz Gatunków; Bogdanowicz, W., Chudzicka, E.; Pilipiuk, I., Skibińska, E., Eds.; Muzeum i Instytut Zoologii PAN: Warszawa, Poland, 2007; pp. 130, $216-217$.

46. Pombi, M.; Marino, V.; Jaenike, J.; Graham-Brown, J.; Bernardini, I.; Lia, R.P.; Beugnet, F.; Miro, G.; Otranto, D. Temperature is a common climatic descriptor of lachryphagous activity period in Phortica variegata (Diptera: Drosophilidae) from multiple geographical locations. Parasites Vectors 2020, 13, 89. [CrossRef] [PubMed]

47. Fauna Europaea. Available online: http:/ / www.faunaeur.org (accessed on 11 December 2020).

48. Falck, M. Phortica variegata (Fallén, 1823) (Diptera, Drosophilidae) new to Norway. Nor. J. Entomol. 2007, 54, 113-114.

49. Gompper, M.E. The dog-human-wildlife interface: Assessing the scope of the problem. In Free-Ranging Dogs and Wildlife Conservation; Gompper, M.E., Ed.; Oxford University Press: Oxford, UK, 2014; pp. 9-54. 